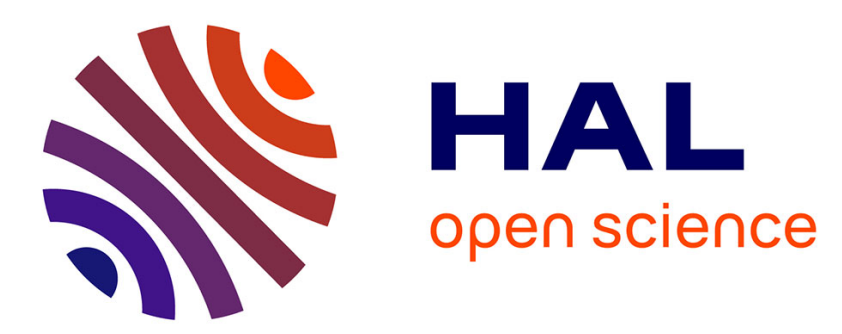

\title{
Floristic composition and spatial distribution of germinable seeds in a spruce plantation
}

\author{
Alvarez, Seis, Bodo Möseler
}

\section{To cite this version:}

Alvarez, Seis, Bodo Möseler. Floristic composition and spatial distribution of germinable seeds in a spruce plantation. Annals of Forest Science, 2012, 69 (5), pp.557-567. 10.1007/s13595-011-0174-z . hal-00930745

\section{HAL Id: hal-00930745 \\ https://hal.science/hal-00930745}

Submitted on 1 Jan 2012

HAL is a multi-disciplinary open access archive for the deposit and dissemination of scientific research documents, whether they are published or not. The documents may come from teaching and research institutions in France or abroad, or from public or private research centers.
L'archive ouverte pluridisciplinaire HAL, est destinée au dépôt et à la diffusion de documents scientifiques de niveau recherche, publiés ou non, émanant des établissements d'enseignement et de recherche français ou étrangers, des laboratoires publics ou privés. 


\title{
Floristic composition and spatial distribution of germinable seeds in a spruce plantation
}

\author{
Miguel Alvarez • Katja Seis • Bodo Maria Möseler
}

Received: 4 August 2011 / Accepted: 19 December 2011 / Published online: 18 January 2012

(C) INRA / Springer-Verlag France 2012

\begin{abstract}
- Introduction The logging of several spruce plantations is planned for the next years in the Eifel National Park (Western Germany). To understand the ecological mechanisms of spontaneous forest regeneration that follows these impacts, it is crucial to investigate the species composition and functional diversity of the buried germinable seeds in those stands.

- Methods We analysed the soil seed bank by germination method and characterised germination dynamics and distribution of seedlings throughout the samples according to a sigmoid model and cumulative curves, respectively. To compare the proportions of functional and syntaxonomical groups between seed bank and aboveground vegetation, we applied the Fisher's exact test. Additionally, we described the spatial distribution of the species in the seed bank according to semivariograms.

- Results The studied seed bank reached a density of about 5,300 seed $\mathrm{m}^{-2}$. Most of the species detected in the seed bank are related to open vegetation, forest fringes and early successional stages of forest regeneration. In spite of a low
\end{abstract}

Handling Editor: Douglass Jacobs

Contribution of the co-authors Experiment was designed and conducted by K. Seis and B.M. Möseler. Statistical analysis of the data was carried out by M. Alvarez. All three authors are responsible for writing this manuscript.

M. Alvarez $(\bowtie) \cdot$ B. M. Möseler

INRES-Vegetation Ecology, Rheinische

Friedrich-Wilhelms-Universität,

Nußallee 9,

53115 Bonn, Germany

e-mail:malvarez@uni-bonn.de

\section{K. Seis}

Institute of Silviculture, Albert-Ludwigs-Universität,

Tennenbacherstr. 4 ,

79085 Freiburg, Germany floristic similarity between seed bank and aboveground vegetation, the functional and syntaxonomical composition is very similar. Further studies considering the distribution of seeds in the soil and the changes of the seed bank composition during the regeneration process are required.

Keywords Beech forest · Epilobietea angustifolii · Norway spruce plantation - Querco-Fagetea - Seed bank density . Spatial distribution pattern

\section{Introduction}

The soil seed bank includes buried germinable seeds as well as seeds lying on the soil surface. Being the starting point of the plant life cycle, the studies focusing on seed bank ecology examined its importance in the maintenance of plant species and plant communities (Harper 1977). Special attention is paid to the potential of their dispersal, both in time (by diaspore longevity) and in space (by morphological or behavioural characteristics). The soil seed bank has potential functions for maintaining the species composition of the vegetation, especially after disturbance events and for the colonization of new areas (Harper 1977). Furthermore, the intact seed bank provides a record of past succession stages of the vegetation and in semi-natural ecosystems - of past land uses (Bossuyt and Hermy 2001; Poschlod et al. 2005). Therefore, the study of the species composition of the seed bank in forest stands can be used to evaluate the floristic shifts in the vegetation by changing management strategies with economic (Augusto et al. 2001) or restoration purposes (van Calster et al. 2008).

Investigations that focused on the functions of seed banks in the restoration of plant communities in Central Europe had been most intensive in grassland ecosystems (e.g. Bakker et al. 1996; Poschlod and Biewer 2005). In a review, Bossuyt 
and Hermy (2001) noted the relatively scarce amount of investigations on seed banks made in forest ecosystems.

Relating to conservation objectives of the Eifel National Park (West Germany), several areas that until now are occupied by Norway spruce (Picea abies) plantations, will be logged for the expansion of the autochthonous beech forests. These areas will be suitable for the spontaneous regeneration of the vegetation, a measure known as "protection of the ecological processes" (in German "Prozessschutz"). Our study site is located in such an area, where logging of the present tree stand is planned for the year 2012. To follow the development of the regeneration dynamics as well as the change in micro-environmental conditions, the Research Centre Jülich started a long-term monitoring in the year 2006 within the framework of the Transregio32 and the Helmholtz Research Initiative Terrestrial Environmental Observatories. In this context, our work group began monitoring the soil seed bank starting in 2007. Since the soil seed bank is potentially an important driving factor for the spontaneous regeneration of a forest stand after logging, especially considering the seeds contained in the superficial layers, the knowledge about its quantitative and qualitative composition can be useful to predict the further succession pathways.

The aim of this work is to determine the density and the species composition of seeds in the soil seed bank of a spruce plantation and to characterize its spatial distribution pattern and functional composition. We hypothesise that the germinable seeds in the soil have an aggregated horizontal distribution, which is the common pattern of seed banks (Thompson 1986). We also expect differences in the distribution of species numbers for the analysed traits as well as in the species composition comparing the aboveground vegetation with the soil seed bank.

\section{Materials and methods}

\subsection{Study site}

Located in the low mountain range Eifel in western Germany, close to the German-Belgian borderline, the study site "Wüstebachtal" is a part of the "Eifel National Park". With a size of about 24 ha, this park covers the upper region of the Wüstebach rivulet $\left(50^{\circ} 30^{\prime} 13^{\prime \prime} \mathrm{N}\right.$ and $\left.6^{\circ} 19^{\prime} 59^{\prime \prime} \mathrm{E}\right)$, including its sources and headwaters, and lies at an altitude of about $600 \mathrm{~m}$ a. s.1. With a low mean annual temperature of $6.5^{\circ} \mathrm{C}$ to $7.0^{\circ} \mathrm{C}$ and a mean annual precipitation of 1,100 to $1,200 \mathrm{~mm}$, the climate is humid, sub-oceanic and belongs to the Köppen's class $\mathrm{Cfb}$ (Peel et al. 2007).

The geological substratum evolved in the early Devonian Period. Typical in this region are the so-called "Wüstebachschiefer", Devonian slates with a high amount of argillite. The soil reaches a depth of 1 to $2 \mathrm{~m}$. Dryer parts at the hillslopes are characterized by haplic and stagnic Cambisols, whereas umbric Stagnosols and umbric Gleysols are typical in the lower parts along the rivulet, according to the FAO soil classification (FAO 2006). The soil texture corresponds to loamy silt. The soil reaction is acidic ( $\mathrm{pH} 2.8$ to 4.0). Mountainous temperate beech forests of acidic soils (association Luzulo-Fagetum) are considered to be the potential natural vegetation in the major part of the study area. In the depressions this vegetation is replaced by the azonal alder forests (association Stellario nemorum-Alnetum), which is adapted to more humid conditions (Pott 1995).

The landscape in the surroundings of the Wüstebach has been heavily influenced in the last centuries by human activities. First historical land use maps document a high amount of forests, heathlands, pastures and meadow orchards. Borchardt et al. (2007) collected more detailed evidence of human activities before the twentieth century. They detected several remnants of charcoal piles as relicts of former forestry use for charcoal production and trenches for pasture irrigation (in German "Flüxgräben"). The first large-scale plantations of spruce were established in the middle of the nineteenth century while the more recent plantation is about 60 years old, established close to the German-Belgian borderline, on battlefields of the Second World War. Traces of those battles are still visible in the field and described in detail by Borchardt et al. (2007).

\subsection{Sampling methods and seed bank analysis}

The sampling was carried out in a spruce plantation located in the headwaters of the Wüstebach rivulet. In order to provide a systematic sampling, we collected soil samples distributed in a grid of $60 \times 60 \mathrm{~m}$. Each intersection constituted one of 50 sampling points; nevertheless, some of them had to be relocated to avoid obstacles like trees or pathways (Fig. 1). The relief is characterised by gentle slopes oriented to the central part of the plantation, where the rivulet is flowing northward. The next beech stands are farther than $3 \mathrm{~km}$ from the sampling locality. In June 2007, 40 soil cores per sampling point within a circular area of $10 \mathrm{~m}^{2}$ were taken. For this purpose, we used steel cylinders with a volume of $250 \mathrm{~cm}^{3}$ ( $8 \mathrm{~cm}$ diameter and $5 \mathrm{~cm}$ depth). For each sampling point the soil cores were merged in the field into one mixed sample. Those samples were taken to the laboratory of the Botanical Gardens in Bonn for further processing. An amount of $3 \mathrm{~L}$ of each mixed sample was spread into plastic trays, over a sterilized organic substratum. The soil layer had a maximum depth of $2 \mathrm{~cm}$. To promote the germination of the seeds contained in the soil samples, the plastic trays had been placed into a greenhouse under daylight and open-climate conditions with temperatures oscillating between -5 and $25^{\circ} \mathrm{C}\left(\right.$ mean $\left.=10^{\circ} \mathrm{C}\right)$ and periodic watering. The trays were randomly distributed and periodically relocated to avoid the influence of spatial effects in the greenhouse. Additionally, some control trays 


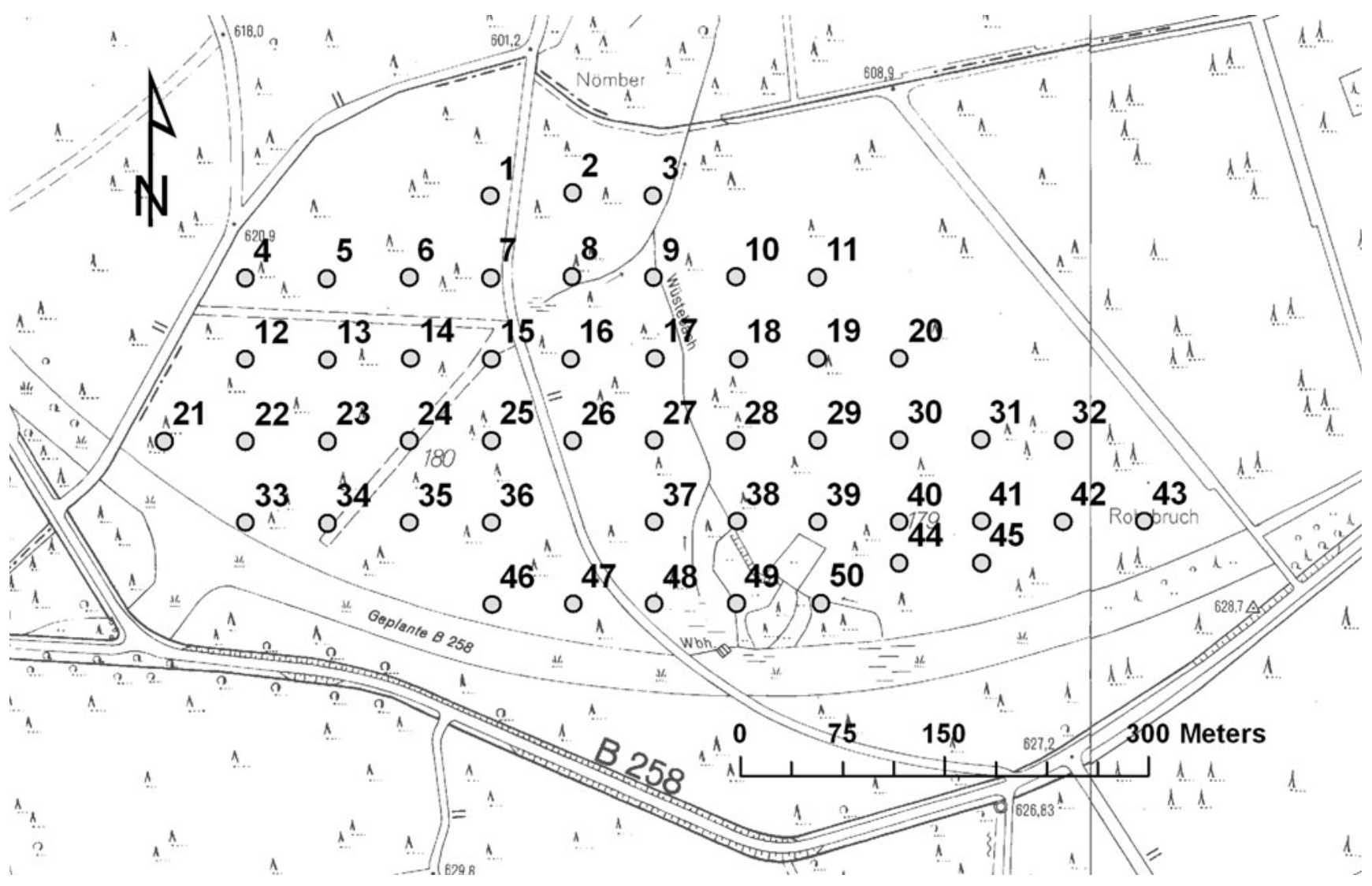

Fig. 1 Distribution of the samples in the study site

were filled only with organic substratum to detect contaminations and seeds dispersed from outside.

During a period of 8 months, the emerged seedlings were periodically counted and determined using literature ad hoc (e.g. Muller 1978). Counted seedlings were removed from the trays to avoid double counting. If determination was not possible, the seedlings (mostly grasses, rushes or sedges) were transplanted in plastic trays filled with organic substratum for determination in a later state using common keys (e.g. Oberdorfer 2001; Tutin et al. 1996). To ensure faster growth of the seedlings, they were placed into a warmer greenhouse $\left(14 \mathrm{~h}\right.$ of light and a mean temperature of $\left.18^{\circ} \mathrm{C}\right)$. The germination experiment started on 18th June 2007. During the sampling, and in successive visits, a complete list of the vascular plant species growing in the study site was compiled.

\subsection{Data analysis}

Many descriptive statistics were calculated to characterize the soil seed bank: mean value and standard deviation of seed densities (in seed $\mathrm{m}^{-2}$ ), diversity after the Shannon index and similarity of the seed bank with the current vegetation using the Jaccard index. All those parameters were compared in a correlation matrix using the Pearson coefficient (Backhaus et al. 2006). The significance of the Pearson coefficient was proved using a two-sided test and a confidence interval of 0.95 .

In order to chart the germination dynamics according to germinated species as well as to the amount of seedlings, we applied the Mercer-Flodin cumulative germination-versustime model (sensu Tjørve 2003). The parameters of the model were estimated by using non-linear least squares.

To describe the species-sample relationship in the seed bank, we carried out a random sorting of the samples 1,000 times to calculate the cumulative species number versus the amount of samples. On this basis, we calculated a mean curve (rarefaction curve sensu Dengler 2009). The cumulative species numbers were also compared with the species present in the vegetation using the Jaccard-index to calculate the increase on the similarity by increasing the amount of samples.

A spatially explicit model was calculated as empirical semivariance according to the formula proposed by Bacaro and Ricotta (2007):

$\gamma(h)=\frac{\sum \text { diss }^{2}}{2 n(h)} \quad$ semivariance

In this formula $\gamma(h)$ is the empirical semivariance as a function of the lag distance $h$, diss is the dissimilarity between two samples and $n(h)$ is the amount of pairwise 
comparisons between samples separated at a distance equal or less than $h$. This calculation was performed for a maximal distance of $360 \mathrm{~m}$, setting the lag distance intervals each at $60 \mathrm{~m}$, which is equal to the separation of the samples in the grid. The semivariance was calculated twice, once using the Bray-Curtis index as dissimilarity and considering the specific seed densities, and once using the Euclidean distance for presence-absence data:

$\operatorname{diss}_{j k}=\frac{\sum\left|x_{i j}-x_{i k}\right|}{\sum\left(x_{i j}+x_{i k}\right)} \quad$ Bray-Curtis index

$\operatorname{diss}_{j k}=\sqrt{\sum\left(x_{i j}-x_{i k}\right)^{2}} \quad$ Euclidean distance

In both equations $\operatorname{diss}_{j k}$ is the dissimilarity between the samples $j$ and $k$, while $x_{i j}$ and $x_{i k}$ are the abundance values of the $i$ th species in the respective samples. Equations 2 and 3 are the dissimilarities according to the Bray-Curtis index and Euclidean distance, respectively (Faith et al. 1987). The Euclidean distance was applied to a presence-absence matrix; therefore, in Eq. 3, $x$ has either the value 1 or 0. Samples 44 and 45 are not considered for the calculation of semivariances to avoid artefacts due to their displacement in the sampling grid (see Fig. 1).

To analyse the distribution of functional traits and syntaxonomical groups, we collected for all sampled species information about their life form (Ellenberg et al. 2001), forest functional group (Schmidt et al. 2003) and syntaxonomical affinity (Oberdorfer 2001). A Fisher's exact test was performed to compare the species number of those groups in the seed bank and in the vegetation considering a significance level of 0.05 (Backhaus et al. 2006).

All statistical analyses were carried out using the $\mathrm{R}$ software environment, including the packages Hmisc, simba and vegan (URL: http://cran.r-project.org).

\section{Results}

\subsection{Seed bank germination}

In the vegetation, 60 vascular plant species were recorded. During the whole germination period, we identified 15,902 seeds of 56 species. This amount corresponds to a mean density of about $5,300 \mathrm{seed}^{-2}$ (Table 1). None of the species could be detected in all 50 samples and the maximal frequencies had been reached by Juncus effusus and Digitalis purpurea, both detected in 49 samples. 12 species had only been detected in the seed bank while 16 species of vegetation were not detected in the seed bank inventories (see Appendix).

Considering the shapes of the germination curves (Fig. 2), most of the seeds and species germinated in the
Table 1 Frequency and seed density of the plant species sampled in the seed bank analysis

\begin{tabular}{|c|c|c|c|}
\hline \multirow[t]{2}{*}{ Species } & \multirow[t]{2}{*}{ Frequency } & \multicolumn{2}{|c|}{ Density $\left(\right.$ seed $\mathrm{m}^{-2}$ ) } \\
\hline & & Mean & $\begin{array}{l}\text { Coefficient } \\
\text { of variance }\end{array}$ \\
\hline Juncus effusus & 49 & $1,778.67$ & 1.45 \\
\hline Digitalis purpurea & 49 & $1,496.00$ & 1.54 \\
\hline Agrostis capillaris & 40 & 512.33 & 1.84 \\
\hline Rubus idaeus & 45 & 352.00 & 1.08 \\
\hline Calluna vulgaris & 39 & 230.67 & 1.47 \\
\hline Luzula luzuloides & 39 & 116.67 & 1.45 \\
\hline Carex flava & 8 & 114.00 & 4.30 \\
\hline Juncus acutiflorus & 8 & 105.33 & 3.50 \\
\hline Carex pilulifera & 32 & 103.67 & 1.50 \\
\hline Agrostis stolonifera s.1. & 17 & 74.67 & 2.68 \\
\hline Carex canescens & 8 & 59.00 & 4.40 \\
\hline Galium saxatile & 25 & 56.33 & 2.87 \\
\hline Stellaria media s.1. & 5 & 49.00 & 6.68 \\
\hline Carex echinata & 3 & 40.67 & 6.95 \\
\hline Carex remota & 11 & 38.33 & 4.13 \\
\hline Deschampsia cespitosa s.l. & 19 & 32.67 & 2.49 \\
\hline Juncus bufonius s.1. & 16 & 19.67 & 2.63 \\
\hline Hypericum maculatum s.l. & 7 & 17.67 & 5.24 \\
\hline Carex ovalis & 4 & 16.33 & 3.83 \\
\hline Betula pendula & 13 & 12.00 & 2.57 \\
\hline Cytisus scoparius & 12 & 10.00 & 2.21 \\
\hline Hypericum perforatum & 6 & 8.67 & 4.79 \\
\hline Cardamine flexuosa & 4 & 7.67 & 3.93 \\
\hline Rumex acetosella s.1. & 12 & 6.67 & 2.31 \\
\hline Alnus glutinosa & 6 & 4.67 & 3.15 \\
\hline Urtica dioica s.l. & 5 & 4.33 & 4.10 \\
\hline Agrostis canina & 2 & 4.00 & 6.50 \\
\hline Viola palustris & 4 & 3.33 & 4.16 \\
\hline Epilobium ciliatum & 9 & 3.00 & 2.16 \\
\hline Potentilla erecta & 6 & 2.67 & 3.18 \\
\hline Scrophularia nodosa & 3 & 2.00 & 4.95 \\
\hline Veronica officinalis & 4 & 2.00 & 4.00 \\
\hline Sagina procumbens & 1 & 1.67 & 7.07 \\
\hline Cirsium palustre & 3 & 1.33 & 4.26 \\
\hline Luzula sylvatica s.l. & 4 & 1.33 & 3.43 \\
\hline Sonchus oleraceus & 4 & 1.33 & 3.43 \\
\hline Carex demissa & 2 & 1.00 & 5.23 \\
\hline Роа аппиа s.l. & 3 & 1.00 & 4.00 \\
\hline $\begin{array}{l}\text { Total (including } \\
\text { skipped species) }\end{array}$ & 50 & $5,300.67$ & 0.87 \\
\hline
\end{tabular}

Mean densities less than 1 seed $\mathrm{m}^{-2}$ are excluded

first 3 to 4 months. In this period, both curves have reached their plateaus. 

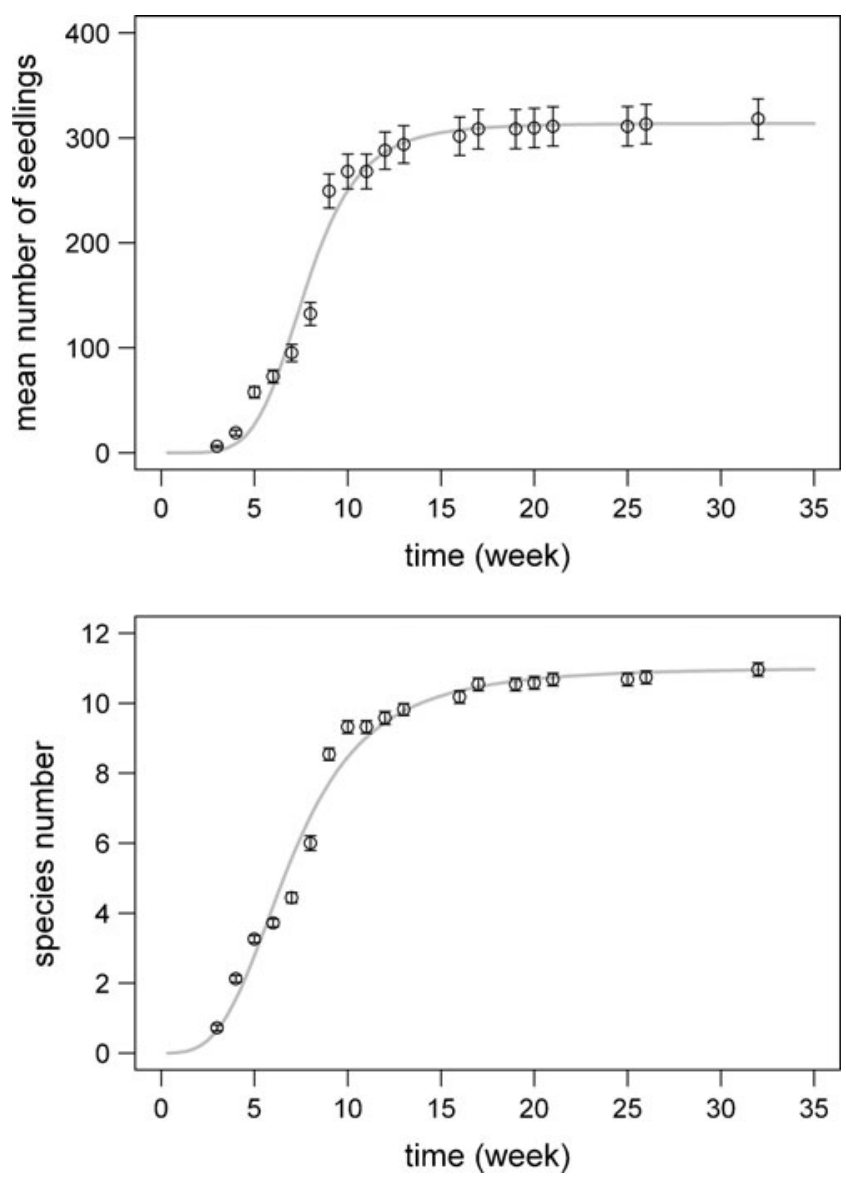

Fig. 2 Cumulative germination in greenhouse. Mean seedlings number (top) and mean species number per tray (bottom) indicated with hollow circles. Error bars, standard error. Grey line, regression using the MorganMercer-Flodin model. Parameters of the model for germinated seedlings: a (upper asymptote) $=313.83, b=60,558.13$ and $c=5.37$. Parameters of the model for germinated species: $\mathrm{a}$ (upper asymptote) $=11.02, \mathrm{~b}=586.81$ and $\mathrm{c}=3.29$

3.2 Spatial distribution pattern of the seed bank

Comparing seed bank's diversity parameters we found only 4 significant correlations (Table 2). From them, the only one with a high value is the correlation between species number and similarity to the aboveground vegetation (0.92) while the only one negative, but slight correlation is between the seed density and the Shannon index $(-0.33)$.

Figure 3 shows the increase of detected species against the amount of analysed samples (rarefaction curve) as well as the increment of the similarity to the vegetation. With 30 samples, the mean curve reaches $87.1 \%$ of all detected species (single curves oscillate between $70.6 \%$ and $100 \%$ ). Though similarities of single samples tend to be very low, ranging from $5 \%$ to $21 \%$, increasing the amount of samples we obtain similarities over $60 \%$. Additionally, the increase of this curve is faster than for the rarefaction (Fig. 3).

Semivariograms have low differences in their shapes comparing the samples either considering the abundance of species (dissimilarity of Bray-Curtis) or not (Euclidean distance; Fig. 4). Semivariance according to the Euclidean distance shows a steadily slow increment by increasing the lag distance (similarity decay) suggesting a homogeneous distribution of the species in the sampling area. Considering the abundance of the species (Bray-Curtis index) the semivariance increases stronger up to a lag distance of $180 \mathrm{~m}$, moreover after this distance there is a low decay on the semivariance, indicating that species occurring in several samples are most abundant than rare species of the seed bank.

\subsection{Functional diversity of the seeds in the soil}

Three aspects of functional diversity (life form, forest functional groups and syntaxonomical affinity) were taken into consideration. Regarding the life form, the above-ground vegetation and the seed bank are dominated by hemicryptophytes (Table 3). All other life forms (phanerophytes, chamaephytes and therophytes) occur in the above-ground vegetation as well as in the seed bank and show very similar patterns. Only in the case of phanerophytes (trees and shrubs) we can see clear differences, as they are better
Table 2 Pearson-correlation coefficients (upper matrix) and respective $p$ values (lower matrix) comparing the diversity parameters of the soil seed bank

\begin{tabular}{lcccc}
\hline & Relief (m a.s.l.) & $\begin{array}{l}\text { Similarity with } \\
\text { vegetation } \\
\text { (Jaccard index) }\end{array}$ & $\begin{array}{l}\text { Seed density } \\
\text { (seeds per sample) }\end{array}$ & $\begin{array}{l}\text { Species number } \\
\text { (species per sample) }\end{array}$ \\
\hline Similarity & -0.161 & & & \\
Seed density & 0.052 & 0.293 & 0.463 & 0.180 \\
Species number & -0.127 & 0.922 & -0.333 & \\
Shannon index & 0.242 & 0.255 & & 0.210 \\
Similarity & 0.265 & 0.039 & 0.001 & \\
Seed density & 0.722 & 0.000 & 0.018 & \\
Species number & 0.381 & 0.074 & & \\
Shannon index & 0.091 & & & \\
\hline
\end{tabular}



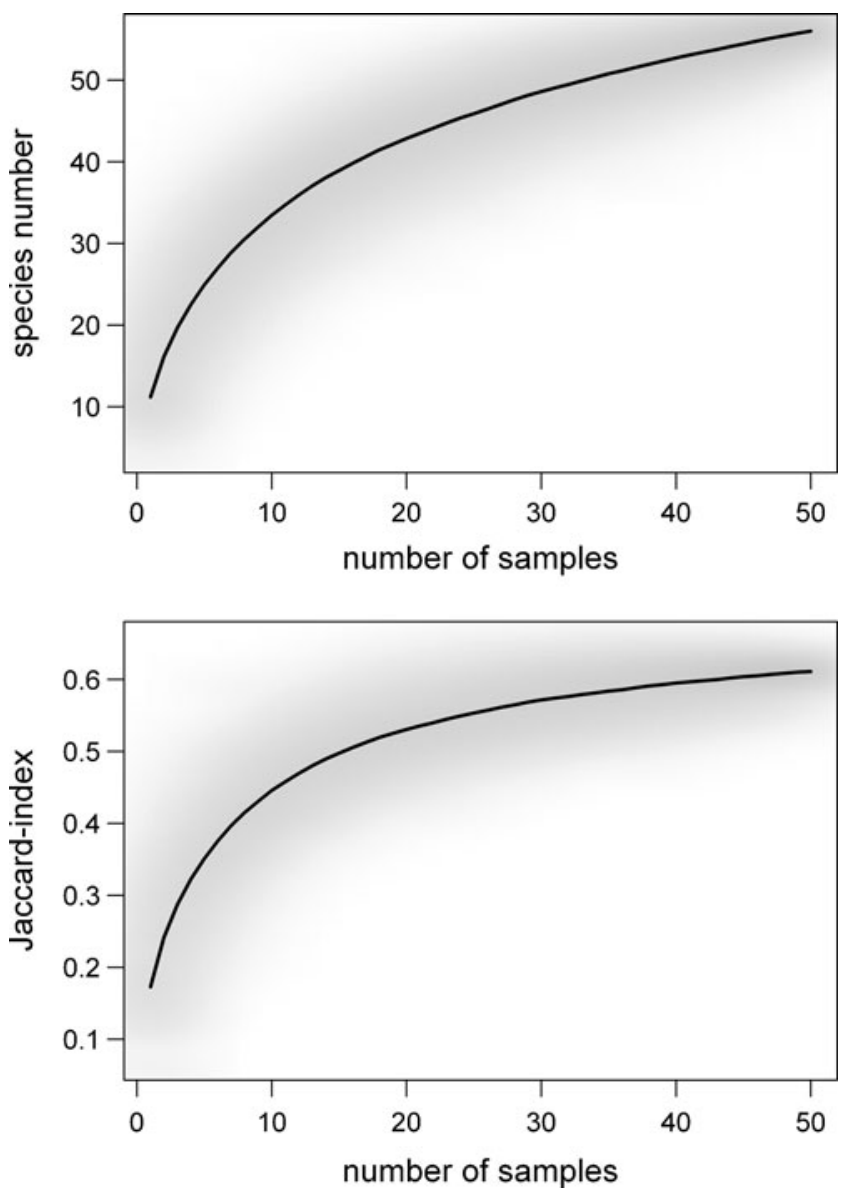

Fig. 3 Rarefaction curve (top) and increase on the similarity to the aboveground vegetation (bottom) after a 1,000-times random selection. Density of random curves showed as grey shadow and mean curve as a black line

represented in the vegetation than in the seed bank. Considering the amount of detected seeds, there is a very strong dominance of hemicryptophytes.

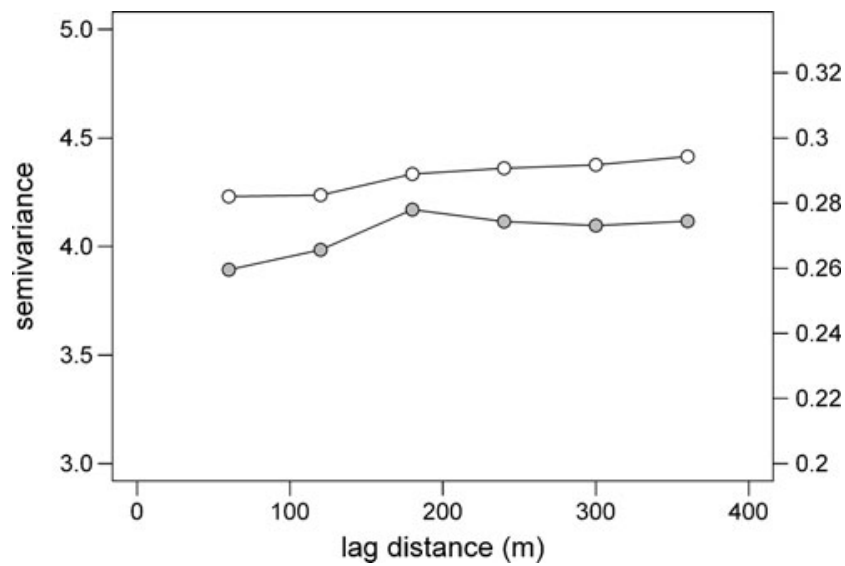

Fig. 4 Empirical semivariogram of the distribution of germinated species in the sampling grid measuring dissimilarities according to the Euclidean distance for presence-absence (white circles, left $y$-axis) and to the Bray-Curtis index (grey circles, right $y$-axis)
Both, the seed bank and the vegetation show a higher number in herb species that are considered to grow in forests as well as in open vegetation. The seed density of herbs of forests as well as of open vegetation (K1.2) and shrubs of closed forests (S2.1) are represented by a high amount of germinated seeds, the last case admittedly represented by only one species: Rubus idaeus.

To analyse the affinity of the species to phytosociological syntaxa, we identified four syntaxonomical classes that are related to the potential vegetation and historical land use forms of the study site. As we can assume a Querco-Fagetea to be the potential climax vegetation on the class level, mid-successional stages belong to Epilobietea angustifolii. Molinio-Arrhenatheretea species are typical for extensively and intensively used grasslands under the given site conditions and Calluno-Ulicetea species represent the vegetation of extensively grazed or burned areas (Pott 1995; Rodwell et al. 2002). A high number of species of the recent vegetation are related to Querco-Fagetea (Table 3). These species are less represented in the seed bank, in the amount of species as well as in the relative amount of germinated seeds. The Epilobietea angustifolii and MolinioArrhenatheretea are represented by a high amount of seeds but with low species numbers (both, in the seed bank and in the vegetation). The Calluno-Ulicetea is represented by four species (Calluna vulgaris, Carex ovalis, Hypericum maculatum s.l. and Potentilla erecta). From them, $C$. vulgaris is the most frequent in the soil samples (see Appendix).

Considering all three categories of species traits (life forms, forest functional groups and syntaxonomical affinity), there are no significant differences in the distribution of species number comparing the vegetation with the seed bank (Table 3).

\section{Discussion}

4.1 Seed bank density, similarity to the vegetation and spatial distribution

The mean seed density in the spruce plantation in the Eifel (about 5,300 seed $\mathrm{m}^{-2}$ ) lies in the span of densities accounted by other studies dealing with European temperate forests. Decocq et al. (2004) found a density of 8,296 seeds $\mathrm{m}^{-2}$ in stands of Querco roboris-Carpinetum betuli in Northern France, Borchers et al. (1998) detected between 2,622 and 7,256 seeds $\mathrm{m}^{-2}$ in stands of Stellario-Carpinetum in Germany, and Ebrecht and Schmidt (2008) as well as Plue et al. (2010) found between 560 and 9,500 seeds $\mathrm{m}^{-2}$ in forests dominated by Fagus sylvatica. Investigations carried out specifically in Norway spruce forests and plantations in Germany, Austria, and Estonia detected between 640 and 15,176 seeds $\mathrm{m}^{-2}$ (Borchers et al. 1998; Berger et al. 2004; Zobel et al. 2007; 
Table 3 Life forms, preferences for forest habitats, and syntaxonomical affinity of the vascular plant species sampled in the vegetation and in the soil seed bank

$V E$ species number in the vegetation, $S B$ species number in the seed bank, $G S$ total germinated seed in the soil samples, $B$ tree layer (forest habitat preferences) $S 2.1$ shrub layer in closed forest (forest habitat preferences), $S 2.2$ shrub layer partly in forest (mainly in open vegetationforest habitat preferences), K1.1 herb layer mainly in closed forest (forest habitat preferences), K1.2 herb layer mainly in forest clearings and at forest fringes, $K 2.1$ herb layer of forest as well as in open vegetation, $K 2.2$ herb layer partly in forest (mainly in open vegetation)

Results of Fisher's exact test comparing the number of species in the vegetation and in the seed bank are expressed as $p$ value

\begin{tabular}{|c|c|c|c|c|c|}
\hline Factor & Classes & VE & SB & GS & $p$ value \\
\hline \multirow[t]{4}{*}{ Life forms } & Phanerophytes & 10 & 6 & 1,139 & \multirow[t]{4}{*}{0.7869} \\
\hline & Chamaephytes & 3 & 2 & 698 & \\
\hline & Hemicryptophytes & 38 & 38 & 13,843 & \\
\hline & Therophytes & 9 & 10 & 222 & \\
\hline \multirow[t]{8}{*}{ Forest habitat preferences } & $\mathrm{B}$ & 5 & 3 & 52 & \multirow[t]{8}{*}{0.7989} \\
\hline & $\mathrm{S} 2.1$ & 3 & 1 & 1,056 & \\
\hline & $\mathrm{S} 2.2$ & 1 & 1 & 30 & \\
\hline & $\mathrm{K} 1.1$ & 6 & 3 & 119 & \\
\hline & $\mathrm{K} 1.2$ & 4 & 3 & 4,512 & \\
\hline & $\mathrm{K} 2.1$ & 26 & 23 & 9,050 & \\
\hline & $\mathrm{K} 2.2$ & 8 & 10 & 547 & \\
\hline & no preference & 7 & 12 & 536 & \\
\hline \multirow[t]{10}{*}{ Phytosociological syntaxa } & Querco-Fagetea & 16 & 9 & 625 & \multirow[t]{10}{*}{0.923} \\
\hline & Molinio-Arrhenatheretea & 7 & 5 & 5,659 & \\
\hline & Epilobietea angustifolii & 4 & 5 & 5,857 & \\
\hline & Stellarietea mediae & 4 & 4 & 154 & \\
\hline & Calluno-Ulicetea & 3 & 4 & 802 & \\
\hline & Vaccinio-Piceetea & 3 & 1 & 2 & \\
\hline & Galio-Urticetea & 2 & 3 & 12 & \\
\hline & Polygono arenastri-Poetea annuae & 2 & 4 & 10 & \\
\hline & Scheuchzerio-Caricetea fuscae & 2 & 6 & 666 & \\
\hline & Other syntaxa & 15 & 15 & 2,115 & \\
\hline
\end{tabular}

Ebrecht and Schmidt 2008). Generally seed banks in temperate European forests and wood plantations have densities that can vary between 100 and 46,000 seeds $\mathrm{m}^{-2}$ (Bossuyt and Hermy 2001).

The similarity between the composition of the seed bank and the current vegetation is very low. The calculated values for the Jaccard index are on average only 0.13 , ranging from 0.05 to 0.21 . These findings coincide with the majority of the results gained from studies of seed banks in forests as they normally show little correspondence in species composition of the current vegetation (Bossuyt and Hermy 2001; Schmidt et al. 2009). However, Amezaga and Onaindia (1997) found that this similarity increases in perennial coniferous plantations compared to laurophyllous forests of the Basque Region in Spain. Schmidt et al. (2009) found also a difference in the similarity between seed bank and vegetation in forests that was higher in mixed woods than in pure beech forests. Since our comparisons are based on presence-absence of species, low similarities are due to a low amount of species occurring simultaneously in the vegetation and in the seed bank. Species occurring exclusively in the vegetation are those that are not able to build a persistent soil seed bank. Species occurring exclusively in the seed bank are to be considered as either remnants from historical land use forms and the corresponding vegetation cover
(Bossuyt and Hermy 2001; Poschlod et al. 2005) or deposited from adjacent stands (Dzwonko 2001).

The significant correlations build the triad "similarity to the aboveground vegetation, species number in the seed bank, and seed density", all of them positively correlated with each other (Table 2). Nevertheless the correlation between similarity and species number is much stronger, indicating that the increase of species in the germinable seed bank also increases the amount of species shared with the aboveground vegetation. The diversity according to the Shannon index comprises both, species richness and relative seed density, therefore an increase of the germinable seeds implies a slight increase on the dominance of some species in the seed bank, reducing the value of the Shannon index. On the contrary, Degen et al. (2005) found a positive relation between density and Shannon index but comparing stands of beech forests with windstorm clearings.

Though the cumulative effect of samples is related to an increase on the detected species as well as an increase in the similarity of the seed bank to the aboveground vegetation (Fig. 3), spatially explicit models as shown by the empirical semivariograms (Fig. 4) suggest an homogeneous distribution of the seeds in the studied stand, contradicting the typical aggregated patterns found in other studies (Thompson 1986). This conclusion is only valid for the scale of the sampling grid used in this work and not applicable to lower scales. 
4.2 Functional classes in the soil seed bank and possible succession pathway

Since none of the classifications of species functional traits shows significant differences when comparing the species composition of the vegetation and the seed bank (Table 3), the contrast considering seed densities is mainly due to the specific production of seeds and probably the variability in their persistence in the soil.

Like Apffelstaedt and Bernhardt (1996), we did not detect any endangered species. Five species detected in the seed bank (Carex remota, Luzula luzuloides, Luzula sylvatica, Oxalis acetosella and Scrophularia nodosa) belong to the "ancient forests indicators" described by Hermy et al. (1999), all of them are also present in the current vegetation. From those, L. luzuloides and C. pilulifera are present in high densities in the seed bank (more than 100 seed $\mathrm{m}^{-2}$ ). This under-representation of species associated to the QuercoFagetea was also found by Schmidt et al. (2009) in mixed and pure beech forests.

The occurrence of plant species related to the Epilobietea angustifolii and Molinio-Arrhenatheretea indicates current or past disturbances. Epilobietea angustifolii contains plant communities of pioneer stages in the succession of forest communities as well as typical vegetation of forest margins (mantle vegetation). This is because pioneer plant species normally produce big amounts of seeds. The MolinioArrhenatheretea includes grassland communities (Oberdorfer 1978; Pott 1995; Rodwell et al. 2002). High amounts of species related to Molinio-Arrhenatheretea in forest seed banks are known from many other works (e.g. Staaf et al. 1987; Augusto et al. 2001; Schmidt et al. 2009). Since many of those species are pioneer ones, they could have the capacity to colonize the studied stand in the early stages of succession after logging. Another link to former vegetation cover is also given by the Calluno-Ulicetea. This class contains anthropogenic heathland communities dominated by the dwarf shrub Calluna vulgaris. Those plant communities were typical succession stages after burnings and fallows, alternating with croplands and grasslands in the region of our study area (Pott 1995). The persistence of seeds added to the soil during past land uses is not easy to proof without long-term experiments. Additionally, species of ruderal vegetation, related to the syntaxa Stellarietea mediae and Polygono arenastri-Poetea annuae, and of oligotrophic swamps (Scheuchzerio-Caricetea) are also well represented in the seed bank (Table 3).

The high frequency of plants associated to open vegetation is also corresponding with the high representation of the forest functional groups K1.2, K2.1 and K2.2, that in general are constituted by herbs of open vegetation and forest fringes. Like in this work, Schmidt et al. (2009) found a high dominance of the group K2.1 (herb layer species that grow in forests as well as in open vegetation) in beech forests from central Germany.

Further studies should be carried out to determine the potential participation of the seed bank during regeneration processes after spruce logging. It can be assumed, that the potential natural vegetation on terrestrial soils is the LuzuloFagetum, and on hydromorphic soils in the depressions along creeks the Stellario nemorum-Alnetum, both communities belonging to the Querco-Fagetea (Oberdorfer 2001). Usually species of early succession stages for those communities belong to the Epilobietea angustifolii (Oberdorfer 1978). These communities are well-represented considering the amount of germinated seeds (Table 3). Although only 4 of the species detected in the seed bank are related to this class, they reach a high seed density in the soil $(1,600$ seed $\mathrm{m}^{-2}$ ). Three of them were found in the current vegetation and in the seed bank (the exception is Fragaria vesca), which indicates that this pool of diaspores is constantly refilled from the recent vegetation.

Strong changes in the species composition with an inflow of diaspores with anemochorous and endozoochorous adaptations can be expected during the regeneration process (Hill and Stevens 1981; Kjellsson 1992; Beismann et al. 1996; Augusto et al. 2001; Degen et al. 2005; van Calster et al. 2008). An additionally important driving force of the succession is the distance to old forest stands that can function as diaspore sources (Rydgren et al. 1998; Dzwonko 2001). After the massive destruction of forest stands due to the battles during the Second World War, the surroundings of the study area were predominantly afforested with fast growing spruce species. The next beech stands are farther than $3 \mathrm{~km}$ from Wüstebachtal. Nevertheless, there is not a consensus in the literature in relation to the relative importance of seed bank and seed immigration. For instance, Apffelstaedt and Bernhardt (1996) stated that the seed bank cannot be considered as important in the regeneration after windfall. Analysing windfall localities in the Vosges Mountains, Augusto et al. (2001) concluded that some - but not all - species could be reestablished from the persistent seed bank.

Models of regeneration in forests stands after disturbance can be carried out in two stages: One determined by the remnant vegetation (including the seed bank and vegetative structures) and a second stage determined by environmental factors and inter-specific competition (Halpern 1989; Verheyen et al. 2003). To investigate the role of the seed bank within succession, long-term observations of the vegetation and seed bank dynamics after clear cutting are necessary, as well as the consideration of more components of the interaction between aboveground and underground vegetation in the regeneration dynamics, such as dispersal syndromes, seed rain and vegetative propagation of plant species. 


\subsection{Concluding remarks}

Since many diaspores and species of the seed bank are related to early successional stages, the current seed bank in the studied Norway spruce stand can potentially participate in the regeneration of the vegetation after logging, allowing the establishment of a more natural ecosystem. Nevertheless, other factors like the change in light conditions due to the structural changes along the successional pathway, as well as an immigration of seeds (seed rain) may also play an important role during the regeneration. The spontaneous recovery of a beech forest stand after logging (by natural succession) may take many years, whereas the species composition of the climax stage can be affected by irreversible alterations in the soil properties. Therefore, active measurements will probably be necessary in the future to allow the establishment of some target species in the forest understory (e.g. ancient forest indicators or endangered plant species).

Acknowledgements The authors would like to thank Henning Walter and Dr. Michael Röös (administrative and research director of the Eifel National Park, respectively) for the facilitation of the fieldwork, the Institute of Chemistry and Dynamics of the Geosphere (ICG) and the Bonn Botanical Gardens for aiding us with the germination experiment, Dipl. Biol. Ute Borchers for providing us with her experiences of former seed bank analysis, and Prof. Dr. Jörg Ewald (University of Applied Sciences Weihenstephan-Triesdorf) for proportioning us the data base of functional traits of forest vascular plant species.

Funding Technical and financial support was provided by the Research Institute Jülich in the context of the Helmholtz Research Initiative Terrestrial Environmental Observatories.

\section{Appendix}

Appendix 1 Plant species lists including their presence in the vegetation and seed bank, their frequency, mean seed number, variance and coefficient of variance in the analysed samples

\begin{tabular}{lcccrrr}
\hline Species & VE & SB & Frequency & Mean & Variance & CV \\
\hline Agrostis canina & VE & SB & 2 & 0.24 & 2.43 & 6.50 \\
Agrostis capillaris & VE & SB & 40 & 30.74 & $3,187.83$ & 1.84 \\
Agrostis stolonifera s.1. & & SB & 17 & 4.48 & 143.93 & 2.68 \\
Alnus glutinosa & VE & SB & 6 & 0.28 & 0.78 & 3.15 \\
Athyrium filix-femina & VE & & & & & \\
Betula pendula & VE & SB & 13 & 0.72 & 3.43 & 2.57 \\
Blechnum spicant & VE & & & & & \\
Calluna vulgaris & VE & SB & 39 & 13.84 & 414.50 & 1.47 \\
Cardamine flexuosa & VE & SB & 4 & 0.46 & 3.27 & 3.93 \\
Carex canescens & VE & SB & 8 & 3.54 & 242.91 & 4.40 \\
Carex demissa & & SB & 2 & 0.06 & 0.10 & 5.27 \\
Carex echinata & & SB & 3 & 2.44 & 287.84 & 6.95 \\
Carex flava & & SB & 8 & 6.84 & 866.42 & 4.30
\end{tabular}

Appendix 1 (continued)

\begin{tabular}{|c|c|c|c|c|c|c|}
\hline Species & VE & SB & Frequency & Mean & Variance & $\mathrm{CV}$ \\
\hline Carex ovalis & & SB & 4 & 0.98 & 14.06 & 3.83 \\
\hline Carex pilulifera & VE & SB & 32 & 6.22 & 86.66 & 1.50 \\
\hline Carex remota & VE & SB & 11 & 2.30 & 90.17 & 4.13 \\
\hline Cirsium palustre & $\mathrm{VE}$ & $\mathrm{SB}$ & 3 & 0.08 & 0.12 & 4.33 \\
\hline Conyza canadensis & VE & $\mathrm{SB}$ & 2 & 0.04 & 0.04 & 5.00 \\
\hline Cytisus scoparius & $\mathrm{VE}$ & SB & 12 & 0.60 & 1.76 & 2.21 \\
\hline $\begin{array}{l}\text { Deschampsia } \\
\text { cespitosa } \text { s.1. }\end{array}$ & $\mathrm{VE}$ & SB & 19 & 1.96 & 23.75 & 2.49 \\
\hline $\begin{array}{l}\text { Deschampsia } \\
\text { flexuosa }\end{array}$ & $\mathrm{VE}$ & & & & & \\
\hline Digitalis purpurea & $\mathrm{VE}$ & $\mathrm{SB}$ & 49 & 89.76 & $18,997.74$ & 1.54 \\
\hline Dryopteris dilatata & $\mathrm{VE}$ & & & & & \\
\hline Epilobium ciliatum & & SB & 9 & 0.18 & 0.15 & 2.15 \\
\hline Fagus sylvatica & VE & & & & & \\
\hline Fragaria vesca & & SB & 1 & 0.02 & 0.02 & 7.07 \\
\hline Galium saxatile & VE & $\mathrm{SB}$ & 25 & 3.38 & 93.91 & 2.87 \\
\hline $\begin{array}{l}\text { Hieracium } \\
\text { lachenalii }\end{array}$ & $\mathrm{VE}$ & & & & & \\
\hline $\begin{array}{l}\text { Hypericum } \\
\quad \text { maculatum s.1. }\end{array}$ & $\mathrm{VE}$ & SB & 7 & 1.06 & 30.87 & 5.24 \\
\hline $\begin{array}{l}\text { Hypericum } \\
\text { perforatum }\end{array}$ & VE & SB & 6 & 0.52 & 6.21 & 4.79 \\
\hline Juncus acutiflorus & $\mathrm{VE}$ & $\mathrm{SB}$ & 8 & 6.32 & 489.41 & 3.50 \\
\hline Juncus bufonius s.l. & $\mathrm{VE}$ & $\mathrm{SB}$ & 16 & 1.18 & 9.66 & 2.63 \\
\hline Juncus bulbosus & & SB & 1 & 0.04 & 0.08 & 7.07 \\
\hline Juncus effusus & $\mathrm{VE}$ & $\mathrm{SB}$ & 49 & 106.72 & $23,970.65$ & 1.45 \\
\hline Luzula congesta & & $\mathrm{SB}$ & 1 & 0.02 & 0.02 & 7.07 \\
\hline Luzula luzuloides & $\mathrm{VE}$ & $\mathrm{SB}$ & 39 & 7.00 & 102.61 & 1.45 \\
\hline Luzula multiflora & & SB & 1 & 0.02 & 0.02 & 7.07 \\
\hline Luzula sylvatica s.l. & $\mathrm{VE}$ & SB & 4 & 0.08 & 0.08 & 3.54 \\
\hline Mercurialis perennis & $\mathrm{VE}$ & & & & & \\
\hline Moehringia trinervia & VE & $\mathrm{SB}$ & 1 & 0.04 & 0.08 & 7.07 \\
\hline Molinia caerulea s.1. & $\mathrm{VE}$ & & & & & \\
\hline Mycelis muralis & $\mathrm{VE}$ & $\mathrm{SB}$ & 1 & 0.02 & 0.02 & 7.07 \\
\hline Oxalis acetosella & VE & $\mathrm{SB}$ & 1 & 0.04 & 0.08 & 7.07 \\
\hline Persicaria maculosa & $\mathrm{VE}$ & SB & 1 & 0.02 & 0.02 & 7.07 \\
\hline Picea abies & $\mathrm{VE}$ & $\mathrm{SB}$ & 2 & 0.04 & 0.04 & 5.00 \\
\hline Picea sitchensis & VE & SB & 1 & 0.02 & 0.02 & 7.07 \\
\hline Plantago major s.l. & & $\mathrm{SB}$ & 1 & 0.02 & 0.02 & 7.07 \\
\hline Pоа аппиа s.l. & $\mathrm{VE}$ & $\mathrm{SB}$ & 3 & 0.06 & 0.06 & 4.08 \\
\hline Poa nemoralis & $\mathrm{VE}$ & & & & & \\
\hline Poa trivialis s.1. & $\mathrm{VE}$ & $\mathrm{SB}$ & 1 & 0.02 & 0.02 & 7.07 \\
\hline Potentilla erecta & VE & $\mathrm{SB}$ & 6 & 0.16 & 0.26 & 3.19 \\
\hline Ranunculus acris & $\mathrm{VE}$ & & & & & \\
\hline $\begin{array}{c}\text { Ranunculus } \\
\text { flammula }\end{array}$ & VE & SB & 1 & 0.02 & 0.02 & 7.07 \\
\hline Rubus fruticosus s.1. & VE & & & & & \\
\hline Rubus idaeus & $\mathrm{VE}$ & SB & 45 & 21.12 & 518.15 & 1.08 \\
\hline Rumex acetosella s.1. & $\mathrm{VE}$ & $\mathrm{SB}$ & 12 & 0.40 & 0.86 & 2.32 \\
\hline Sagina procumbens & VE & $\mathrm{SB}$ & 1 & 0.10 & 0.50 & 7.07 \\
\hline Sambucus nigra & VE & & & & & \\
\hline Scrophularia nodosa & $\mathrm{VE}$ & SB & 3 & 0.12 & 0.35 & 4.93 \\
\hline Senecio ovatus & VE & & & & & \\
\hline Senecio sylvaticus & VE & SB & 1 & 0.02 & 0.02 & 7.07 \\
\hline
\end{tabular}


Appendix 1 (continued)

\begin{tabular}{|c|c|c|c|c|c|c|}
\hline Species & VE & SB & Frequency & Mean & Variance & $\mathrm{CV}$ \\
\hline Sonchus asper & VE & SB & 2 & 0.04 & 0.04 & 5.00 \\
\hline Sonchus oleraceus & VE & SB & 4 & 0.08 & 0.08 & 3.5 \\
\hline Sorbus aисирагіa & VE & & & & & \\
\hline Spergularia rubra & & SB & 1 & 0.02 & 0.02 & 7.0 \\
\hline Stachys sylvatica & $\mathrm{VE}$ & & & & & \\
\hline Stellaria media s.1. & VE & SB & 5 & 2.94 & 385.94 & 6.6 \\
\hline Taraxacum officinale s.l. & $\mathrm{VE}$ & SB & 2 & 0.04 & 0.04 & 5.0 \\
\hline Urtica dioica s.l. & $\mathrm{VE}$ & SB & 5 & 0.26 & 1.14 & 4.1 \\
\hline Vaccinium myrtillus & VE & & & & & \\
\hline Veronica officinalis & VE & SB & 4 & 0.12 & 0.23 & 4.0 \\
\hline Viola palustris & VE & SB & 4 & 0.20 & 0.69 & 4. \\
\hline
\end{tabular}

$V E$ presence in the vegetation, $S B$ presence in the seed bank, $C V$ coefficient of variance

\section{References}

Amezaga I, Onaindia M (1997) The effect of evergreen and deciduous coniferous plantations on the field layer and seed bank woodlands. Ecography 20:308-318

Apffelstaedt F, Bernhardt K-G (1996) Vegetations- und populationsbiologische Untersuchungen zur Dynamik von Naturwaldzellen und Windwurfflächen in Nordrhein-Westfalen. Tuexenia 16:43-63

Augusto L, Dupouey J-L, Picard J-F, Ranger J (2001) Potential contribution of the seed bank in coniferous plantations to the restoration of native deciduous forest vegetation. Acta Oecol 22:87-98

Bacaro G, Ricotta C (2007) A spatially explicit measure of beta diversity. Comm Ecol 8:41-46

Backhaus K, Erichson B, Plinke W, Weiber R (2006) Multivariate Analysemethoden. Springer, Berlin

Bakker JP, Poschlod P, Strykstra RJ, Bekker RM, Thompson K (1996) Seed banks and seed dispersal: important topics in restoration ecology. Acta Bot Neerl 45:461-490

Beismann H, Kollmann J, Bogenrieder A, Speck T (1996) Reconstruction of local vegetation patterns by seed bank analysis - results from three case studies in the Upper Rhine region, Germany. Neues Jahrbuch für Mineralogie, Geologie und Paläontologie, Abhandlungen 2:169181

Berger TW, Sun B, Glatzel G (2004) Soil seed bank of pure spruce (Picea abies) and adjacent mixed species stands. Plant Soil 264:53-67

Borchardt H, Lehmkuhl F, Röös M (2007) Einsatzmöglichkeiten von GIS und digitalen Geländemodellen bei der Rekonstruktion historischer Landnutzungsformen. Kartographische Schriften 13:155-166

Borchers U, Möseler BM, Wolf G (1998) Diasporenreservoir in Fichtenforsten und Eichen-Heinbuchenwäldern. Naturschutz und Landschaftsplanung 30:10-16

Bossuyt B, Hermy M (2001) Influence of land use history on seed banks in European temperate forest ecosystems: a review. Ecography 24:225-238

Decocq G, Valentin B, Benoit T, Hendoux F, Saguez R, Bardat J (2004) Soil seed bank composition and diversity in a managed temperate deciduous forest. Biodivers Conserv 13:24852509

Degen T, Devillez F, Jacquemart A-L (2005) Gaps promote plant diversity in beech forests (Luzulo-Fagetum), North Vosges, France. Ann For Sci 62:429-440
Dengler J (2009) Which function describes the species-area relationship best? A review and empirical evaluation. J Biogeogr 36:728744

Dzwonko Z (2001) Effect of proximity to ancient deciduous woodland on restoration of the field layer vegetation in a pine plantation. Ecography 24:198-204

Ebrecht L, Schmidt W (2008) Bedeutung der Bodensamenbank und des Diasporentransports durch Forstmaschinen für die Entwicklung der Vegetation auf Rückegassen. Forstarchiv 79:91-105

Ellenberg H, Weber HE, Düll R, Wirth V, Werner W (2001) Zeigerwerte von Pflanzen in Mitteleuropa. Erich Goltze, Göttingen

Faith DP, Minchin PR, Belbin L (1987) Compositional dissimilarity as a robust measure of ecological distance. Vegetatio 69:57-68

FAO (2006) World reference base for soil resources 2006 - a framework for international classification, correlation and communication. FAO, Rome

Halpern CB (1989) Early successional patterns of forest species: interactions of life history traits and disturbance. Ecology 70:704-720

Harper JL (1977) Population biology of plants. Academic, London

Hermy M, Honnay O, Firbank L, Grashof-Bokdam C, Lawesson JE (1999) An ecological comparison between ancient and other forest plant species of Europe, and the implications for forest conservation. Biol Conserv 91:9-22

Hill MO, Stevens PA (1981) The density of viable seed in soils of forest plantations in upland Britain. J Ecol 69:693-709

Kjellsson G (1992) Seed banks in Danish deciduous forests: species composition, seed influx and distribution pattern in soil. Ecography 15:86-100

Muller FM (1978) Seedling of the North-Western European lowland. Dr. W. Junk, Wageningen

Oberdorfer E (1978) Süddeutsche Pflanzengesellschaften, part II. Gustav Fischer, Stuttgart

Oberdorfer E (2001) Pflanzensoziologische Exkursionsflora für Deutschland und angrenzende Gebiete. Eugen Ulmer, Stuttgart

Peel MC, Finlayson BL, McMahon TA (2007) Updated world map of the Köppen-Geiger climate classification. Hydrol Earth Syst Sci 11:1633-1644

Plue J, van Gils B, Peppler-Lisbach C, de Schrijver A, Verheyen K, Hermy M (2010) Seed-bank convergence under different tree species during forest development. Perspect Plant Ecol Evol Syst 12:211-218

Poschlod P, Biewer H (2005) Diaspore and gap availability are limiting species richness in wet meadows. Folia Geobot 40:13-34

Poschlod P, Bakker JP, Kahmen S (2005) Changing land use and its impact on biodiversity. Basic Appl Ecol 6:93-98

Pott R (1995) Die Pflanzengesellschaften Deutschlands. Eugen Ulmer, Stuttgart

Rodwell JS, Schaminée JHJ, Mucina L, Pignatti S, Dring J, Moss D (2002) The diversity of European vegetation. EC-LNV, Wageningen

Rydgren K, Hestmark G, Økland RH (1998) Revegetation following experimental disturbance in a boreal old-growth Picea abies forest. J Veg Sci 9:763-776

Schmidt M, Ewald J, Fischer A, von Oheimb G, Kriebitzsch W-U, Ellenberg H, Schmidt W (2003) Liste der in Deutschland typischen Waldgefäßpflanzen. Mitteilungen der Bundesforschungsanstalt für Forst- und Holzwirtschaft 212:1-35

Schmidt I, Leuschner C, Mölder A, Schmidt W (2009) Structure and composition of the seed bank in monospecific and tree species-rich temperate broad-leaved forests. For Ecol Manage 257:695-702

Staaf H, Jonsson M, Olsén L-G (1987) Buried germinative seeds in mature beech forests with different herbaceous vegetation and soil types. Holarctic Ecol 10:268-277

Thompson K (1986) Small-scale heterogeneity in the seed bank of an acidic grassland. J Ecol 74:733-738

Tjørve E (2003) Shapes and functions of species-area curves: a review of possible models. J Biogeogr 30:827-835 
Tutin T, Burges N, Chater A, Edmonson J, Heywood V, Moore D, Valentine D, Walters S, Webb D (1996) Flora Europaea. Cambridge University, Cambridge

van Calster H, Chevalier R, van Wyngene B, Archaux F, Verheyen K, Hermy M (2008) Long-term seed bank dynamics in a temperate forest under conversion from coppice-with-standards to high forest management. Appl Veg Sci 11:251-260
Verheyen K, Guntenspergen GR, Biesbrouck B, Hermy M (2003) An integrated analysis of the effects of past land use on forest herb colonization at the landscape scale. J Ecol 91:731-742

Zobel M, Kalamees R, Püssa K, Roosaluste E, Moora M (2007) Soil seed bank and vegetation in mixed coniferous forest stands with different disturbance regimes. For Ecol Manage 250:71-76 